\title{
Domination of Conservative Traditionalists over the Development of Middle Eastern Countries
}

\author{
Ali Akbar Ramazaniandarzi*; Mehrzad Javadikouchaksaraei \\ Email: ramazanina2003@yahoo.com
}

\begin{abstract}
Given the special political, cultural, historical, and religious conditions in the Middle East, the conservative elites in these regions have enhanced their commitment to their traditions and have opposed any changes in their societies. The most important feature of this conservative traditionalism is that it does not tolerate uneven economic development. However, this feature is inapplicable to political and social development.
\end{abstract}

KeyWords: Development; Development and Underdevelopment; Elitism; Tradition and Traditionalism; Conservatism; Rentier

\section{Introduction}

After World War II, several countries around the world defined the term "development" according to their own criteria.

These criteria label a country as "developed" according to its economy, political situation, institutions, choices of their leaders, and socio-cultural issues. Countries are classified into modern or non-modern, developed or underdeveloped, north or south, and first world or third world. This classification raises several important questions, such as what makes some countries more developed than others and why traditional or semi-traditional conditions still exist in some modern countries. This paper studies the underdevelopment of Middle Eastern countries by focusing on the cultural and political statuses of the elites in these regions. Development cannot be achieved without effective political management and political managers. Strategic elites are involved in the development of economic and political goals in Middle Eastern countries.

\subsection{Development and underdevelopment}

Many scholars have proposed theories about the radical changes that took place in the 1950s and 1960s. They believe that all communities were placed under either a traditional or an underdeveloped state of modernization. Some theories on the cultural or economic factors, as well as on the social development of 
these communities, are largely pessimistic. The development concept was initially explained by three theories. Martin Seymour Lipset proposed a development plan in accordance with the requirements of democratic legitimacy. Other researchers have focused on the cultural traditions of countries, including their national institutions (i.e., national flag, anthem, shows, or parades) and governments, which they believe are crucial in fostering loyalty and national consciousness among fellow citizens (Sai, 2004).

One of the key ideas in the course of modernization is the linear path of Walt W. Rostow that discusses economic and political development stages.

Theories on development are ranked as follows:

- Theories that prioritize infrastructures

- Theories that prioritize culture

- Theories that prioritize political factors related to economic development

- Theories that prioritize economy over politics (Ibid)

In this paper, the development of each community structure is analyzed separately to arrive at a single conclusion.

\subsubsection{Social and Cultural Development}

The different types of interactions that take place within a community and encompass a broad scope can lead to the development of a new civilization. Structure is usually linked to social development because of the broad concept of social construction. However, the value of cultural development, the immaterial needs of societies, and the perceptions, values, attitudes, actions, and behaviors that human beings form as a result of abandoning cultural and subcultural development become difficult to analyze with time. Weber argued that cultural development precedes other kinds of development and that modernization is associated with rationalization. The effects of rationalization, disenchantment, religion, and culture on social transition are studied by analyzing the role of culture in modernization.

\subsubsection{Political Development}

Rather than focusing on traditional behavioral patterns, political development emphasizes the effectiveness of governments, the formation of new behavioral patterns, the public participation in governance, and the roles of governments and elites.Political development is usually assessed at four levels, namely, government institutions, political communities or parties, civil society, and public domain. Robert Dahl (1991) argued that modern democracy differs from other forms of governance in the following aspects:

\section{1) Government elections}

2) Freedom to vote

3) Freedom of expression

4) Availability of alternative and independent sources of information 
5) Independent and sovereign populations

6) Rights of citizens

S. N. Eisenstein (1995) gave a comprehensive view of policy development that involved the following elements:

1) Diversify political and professional structure

2) Increasing number of legal, political, and administrative activities

3) Penetration and permeation of all spheres of society

4) Decentralization of policies

5) Distribution of political power in all sectors of the society

6) Weakening of the traditional elite (Abedi-Ardekani, 2001).

\subsubsection{Economic Development}

Economic development increases the production capacity of a technology-based society. Economic theory can be divided into four categories, namely, dependency, neo-Marxist, world systems theory, and internal colonialism (Chylkvt, 1996). The basic concept of development can be defined and proved with numbers. When development covers a series of social, political, economic, and cultural issues, people are in a better position to control the development of their communities.

Economic development also covers the following: degree of urbanization; level of literacy; development of mass media and community organizations; formation of rational and general behaviors; involvement of communities; formation of political relationships based on mutual trust and accountability; effectiveness of community leaders and policy managers; emergence of institutions such as political parties and associations; establishment of a democratic society; organization of elections for selecting leaders; creation of private, non-government, civil, social, health-related, and educational organizations; fair distribution of wealth and power; achievement of favorable economic; industrialization, production, and employment levels; participation of women in eradicating poverty; and elimination of rent.

\subsubsection{Underdevelopment}

Clearly, the criteria for development cannot be used to determine the degree of underdevelopment of a society.Underdevelopment can be evaluated by assessing political management, percentage of the poor population, measures for population control, availability of economic opportunities, economic and cultural duality, illiteracy, unemployment and non-employment, poverty, health, inflation, weaknesses in economic and social management, availability of skilled workers, deficiency in human and financial resources, distribution of income, life expectancy and longevity, nutrition, migration, brain drain, and use of natural resources. 


\subsubsection{Elitism}

Elites include intellectuals, writers, critics, artists, politicians, military officers, senior managers, owners of multinational corporations, and other influential people.

Elitism can be viewed from the following perspectives:

1) Classical elitism believes that the oligarchic rotation of the elite can be proved through historical experience.

2) Democratic elitism, which was proposed by Max Weber and Joseph Schumpeter, argues that the participation of elites in the implementation of social policies has made them a powerful force in the society. Max Weber also considered democracy as an alternative means to ensure fair governance.

3) Modern elitism, which was proposed by C. Wright Mills and Walter Burnham (1975), argues that in the United States, the members of the smaller class occupy most of the key positions in the society. These members also live interdependently because of their common social origins and family relations.

Elitism divides the society into three categories, namely, person classy, people quadratic, and nonpolitical.

\subsubsection{Rentier State}

Rent-seeking theory of bargaining agents reviews the market intervention and manipulation of the government. Bargaining agents obtain the market by bargaining with the government rather than by following the logic of the market. Many countries, especially those in the Middle East, Africa, and Latin America, are considered rentier states. Rent-seeking theory assumes that the governments of rentier states rely heavily on external income and the distribution of this income in the society. The governments of rentier states rely on revenues generated from particular commodities, such as oil, diamonds, guns, and canes. Therefore, these countries can generate a sufficient amount of funds with minimal effort.

Rentier states are characterized by the following:

1) Reliance on external resources and independence from the domestic economy in resource allocation

2) Concerns over the legitimacy of social support

3) Payment of "hush money" and the suppression of law violators

4) Patrimonialism, in which all power flows directly from the leader. The leading elites place themselves at the center of a network of activities.

The governments of entire states also show great interest in the creation of personality cults (Kouchaksaraei, 2012).

\subsubsection{Social and Philosophical Traditions of Political Activism}

Tradition and traditionalism in the Middle East should be viewed from the two following perspectives: 


\subsubsection{Perspective of Islamic scholars}

Rene Guenon, Firhtiof Schuon, Martin Lings, Hussein Nasr, and Ananda Coomaraswamy proposed the sacred tradition concept to explain the attitudes of religious traditionalists toward modernity and modernism.

The sacred tradition concept also explains the philosophy and traditions of different religions around the world. Religious traditionalists aim to maintain the integrity and effectiveness of their religious heritage. Rene Guenon (1927) argued that Eastern traditions should be given special attention because such traditions are still intact. Guenon believed that the situation of the modern world could not be clarified through periodic training. His theories on the nature of time, space, and matter, which were all based on traditional cosmology, were closely associated with the teachings of his period.

Guenon believed that the time, place, territory, and qualitative differences in nature are fixed and could not be changed. The concept of self-contained conceptual material is incompatible with the concept of self-organization and sciences. Guenon also argued that people should rely on principles supported by facts and pursue these principles in metaphysical and cosmological sciences.

The thoughts of these Islamic scholars can be divided into the three following parts:

1) People must focus on their daily social and political issues as well as on the relationship between the present and the past and between the East and the West.

2) People must devote themselves to traditional arts and crafts to enhance their ambition.

3) Preoccupying oneself with religious and metaphysical questions can help form a unique balance between grace and skill to help develop metaphysical conviction.

Traditional art has the two following objectives:

1) To satisfy the present needs.

2) To preserve and disseminate moral and spiritual teachings that mark the emergence of traditional Eastern art as a unique art (Panahi, 2012).

Hussein Nasr (1990) argued that the tradition concept includes the true meaning of the divine origin. The removal or restoration of divine messages continues throughout the course of human history. The meanings of tradition are closely associated with the philosophy of immortality and the constant revival by horizontal or vertical movement as continuity exists at the beginning of here and now (Nasr, 2001). Alasdair Macintyre (1990), a non-Muslim traditionalist, emphasized the teachings of Christian theology and Aristotelian philosophy and was influenced by the ideas of Thomas Aquinas. McIntyre rejected the ideas of enlightenment, modernism, individualism, and liberalism yet defended the Aristotelian tradition (Bashirieh, 1999). Traditional Christian theology has three elements, namely, teachings from God, teachings from humans, and the transfer of these teachings (Tabatabaei, 2010).

\subsubsection{Sociological perspective}

Other researchers have adopted a sociological approach to define the concept of tradition in a narrow sense. However, the most commonly used approaches primarily focus on the oral transmission of sacred traditions, tastes, principles, beliefs, and customs from one generation to another (Abedi-Ardekani, (2001). 
Tradition refers to the ethical and knowledge-intensive practices that a parent passes on to a child. Tradition has the following features:

1) Focused on the concepts of continuity, stability, and dignity

2) Collective wisdom

3) Dominance in the society

4) Source of legitimacy

5) Rooted in the past

6) Has a special place in sacred tradition

7) Focused on the most important areas of life, such as kinship, religion, culture, literature, and art

In the book Economy and Society, Max Weber discussed the conflict between social and traditional practices. Weber also defined tradition as a behavioral response closely related to normal stimuli. He added that traditional practices might become conscious activities that could lead to value-oriented rationality.

Weber also provided the following arguments:

1) The first action of an individual is normal or natural.

2) A certain behavior becomes a norm when it is displayed self-consciously in daily social interactions (Ibid).

Hoselitz (1953) defined action as a vital event that takes place within a particular context and could shift traditionalism by making an explicit and direct reference to the history of a community. The table1 below outlines the idea of Hoselitz.

Table 1 Types and classification of traditional practices

\begin{tabular}{|l|l|l|l|}
\hline Habit & Unscheduled & Unconscious & Dissonance \\
\hline Traditions and customs & Unscheduled & Unconscious & Normative \\
\hline Norm & Unscheduled & Conscious & Normative \\
\hline Ideology & Scheduled & Conscious & Normative \\
\hline
\end{tabular}

3) Traditionalism also has its own political attitude, which is further discussed in the subsequent paragraphs. 


\subsubsection{Attitudes of Elites Toward Traditionalism}

Many scholars believe that the political attitudes and the psychological tendencies of individuals to commit a political action are influenced by several factors, such as historical traditions, memories, motivations, and institutional or political emotions (Almond \& Verba ,1963).

However, the most important of these factors is the tradition of elites, who are known for preserving and exploiting their personal interests in a political society. The state government is considered conservative because its passive status hardly changes. The government also produces a conservative effect on the society by creating a situation in which individuals are less inclined to think. The political attitudes of traditionalists are reflected in their strong opposition to changes in their current affairs and political foundations, their neutralization of the current changes, and their desire to return to the past (13). By investigating the relationship between Islam and modernity, Barbier found that political Islam is largely unfamiliar with political modernity (Maurice, 1996).

\subsection{Conservatives and conservatism}

Historical and scientific conservatism was introduced in the 1830s. Upon its introduction, the term "conservatism" was adopted from France to England. People in Europe who were affected by the revolutionary ideas of the Enlightenment opposed the concept of conservatism. Master thinkers Joseph Vincent from France and Klemens von Metternich from Austria actively opposed the French Revolution and the separation of the church and state. They believed that the concepts of progress and equality were unacceptable. Conservatives also reject the idea of abstraction, which may result in vast societal changes, and argue that such an idea is impossible to execute and learn. Conservatives aim to dominate the minds of people to promote the idea that no society cannot function without the influence of religion and ethics. These ideas, including public and legislative measures such as the right to form caucuses, have always been meant to look doubtful. Conservatives aim to ascertain that issues are straightforward, elusive, and complex. According to Aukshat, conservatives prefer the known over the unknown (Oakeshott, 1962). The definition of conservatism as proposed by Mannheim completely disagrees with the modern definition of this concept. Mannheim argued that the main idea of conservatism is to oppose the fundamental concepts of the bourgeois society, the philosophy of natural rights and social contract, the sovereignty of originality, and the sense of individual freedom, equality, and its components (Bashirieh, 2007).

The features of conservatism are as follows:

1) Strong support and commitment to conservative ideas

2) Strong support and commitment to tradition

3) Strong deference to traditional religious beliefs. Samuel Taylor Coleridge (1798) found a close relationship between conservatism and religion. Conservatives believe that the ultimate purpose of God is to produce human life, uplift human rights, and monitor the duties that arise. Edmund argued that humans are naturally religious (Tabatabai, 2010).

4) Strong support and commitment to congregations and the traditional collective interests of the society. Congregations can serve as a focal point for people with similar interests.

5) Strong support and commitment to hierarchies.

6) Conservatives form their identities, traditions, and religion, according to their history (Savedji, 1999). 
7) Pessimism toward the intellect of man. Reform conservatives are skeptical about the reasoning of humans, which lies in their tradition or religion.

8) Respect for natural inequalities. Unlike liberals, conservatives argue that ownership is a natural right of man and that man unquestionably accepts all forms of ownership.

9) Display of patriarchal attitudes. Conservative individuals and communities are known for their mutual dependence and sense of responsibility.

10) Display of elitism. Conservatives perceive people as equally wise yet argue that some individuals are meant to lead others (Bashirieh, 2006).

\section{Discussion and Analysis}

The Middle East, which ranges from the Mediterranean to the Indian subcontinent as well as from the neighboring countries in Northern Africa to those in Southern Europe, is known for having the oldest civilization in the world. This region is also home to the three great religions of Judaism, Christianity, and Islam. The Middle East has a great number of underground resources that have brought massive wealth to surrounding countries. These underground reservoirs have also significantly affected the lives of the local people.

Islam is the dominant religion in the region, with majority of the population being ethnic Arabs. Most countries in this region achieved independence from the 1950s to the late 1970s. People in these countries still practice ancient manners, customs, cultures, and traditions, which have set the framework for governments. People in the Middle East also create an environment in which they preserve their surviving traditions similar to how they preserve their energy resources. Despite witnessing a rapid economic growth prior to 2010, gaining massive wealth, and utilizing their underground resources, countries in the Middle East have failed to achieve an all-around development. As shown in their balance of payments, the countries in the region have achieved an economic growth rate of approximately 6.4 before 2010 . However, these countries have spent almost 10 years to achieve such growth (Ibid). This paper investigates several countries in the Middle East, including Saudi Arabia, Jordan, Kuwait, Iran, Syria, Lebanon, Turkey, Iraq, United Arab Emirates, Yemen, Bahrain, Oman, Egypt, and Qatar. Most of these countries depend on their groundwater resources, such as oil, for their economic growth. Although gasrich countries have the necessary resources to implement changes in their systems, they are still considered rentier states.

A. The shared social and cultural features of Middle Eastern countries are as follows:

1) Economic dependence on one or two products

2) Economic dualism (i.e., countries that are both industrialists and capitalists, such as Iraq and Iran)

3) Massive unemployment and underemployment rates, which indicate their inefficient rotation of capital

4) Low standard of living

5) High gross national income per capita

6) High gross domestic product

7) Unequal distribution of national income

8) Poverty 
9) Khalifa-ruled families and the legacy of activism

10) Traditional rulers

11) Conflicts between ethnic and religious groups

12) Coexistence of traditional and modern practices

13) Rentier states (Bashirieh, 2006)

B. Individual characteristics of the intellectual elite in Middle Eastern countries

Elites have an increasing importance in the Middle East because of the dramatic changes in their societies and the resistance of people against their rulers.

\subsection{Idiosyncrasies and individual qualities of rulers in the Middle East}

1) Social and political roots of the Islamic-Arabic traditionalists

2) Division of political traditionalists into Shi'as and Sunnis, which are characterized as follows:

a) Shi'as abides by the ideas of Imam and Velayate. They also uphold the ideas of reservation and martyrdom. Shia's are generally expedient and abide by their constitution.

b) Both Shia's and Sunnis are known for their charismatic leadership.

c) Sunnis solve their problems and make their decisions according to nationalism and salinity.

3) Fatalism and the inability to analyze worldwide issues and events

4) Moral absolutism

5) Anti-modernity

6) Opposition to the new age (Stenographer, 1994)

7) Reverence for history, which they demonstrate through the following activities:

a) Authentication of the past

b) Revival of religious traditions

8) World problems can be resolved through changes in man himself and not by changing the outside world i) Driven man from the Garden of Eden, try hard to come back to the premier world

9) The sources of knowledge may include the following:

a. Data inspiration;

b. Mystical discovery; and

c. Thinking and reasoning (as opposed to inductive and deductive reasoning). 
10) Traditionalists uphold traditionalism, which is the basis of the following:
a. Identity;
b. Legitimacy; and
c. Authority.

11) The traditionalists' view of science includes the following:
a. Refusing to think about other principles and religious values;
b. Lack of criticism of the traditions;
c. The belief that one's religious and theological knowledge is superior to others; and
d. Discussion only the basis of their problems and do not argue for the independence of (Afshin-Nia, 2006)

12) The Lord of the traditionalists states that:
a. Source and destination will be determined by the fate of the man of God; and
b. God is not evil (Norton, 2003).
C. Situation in the Middle East from the aspect of development

Even before the year 2010, a various studies have been conducted on the development of the situation in the Middle East. The current study selected this period because it demonstrated the stability of the Middle East after the Iraq War.The political, economic, and social statistics in Middle Eastern countries are not good, and the rulers have become the major influence of changes in these countries. In addition, various problems, such as women's issues, education and health, have continued to increase in these countries. Based on Table 2, Table 3 and Table 4, the statistics involved in the development issues are considered the world's benchmark measure.

Table 2 The main features of the Middle East countries

\begin{tabular}{|l|c|c|c|c|c|c|c|c|c|}
\hline Features & Egypt & Iran & Jordan & Kuwait & Qatar & Saudi & Syria & UAE & Yemen \\
\hline Population & 64 & 64 & 5 & 2 & 0.58 & 20.7 & 16.2 & 3 & 17.5 \\
\hline $\begin{array}{l}\text { Urban } \\
\text { population }\end{array}$ & 43 & 64 & 79 & 96 & 93 & 86 & 51 & 86 & 25 \\
\hline $\begin{array}{l}\text { Population } \\
\text { Growth }\end{array}$ & 1.9 & 1.5 & 3.1 & 4.6 & 3 & 2.6 & 2.6 & 4.4 & 2.9 \\
\hline GNI & 3510 & 5710 & 3810 & 22290 & 0 & 13490 & 3130 & 0 & 730 \\
\hline $\begin{array}{l}\text { The per } \\
\text { capita }\end{array}$ & 224 & 364 & 18.6 & 44.2 & 0 & 280 & 50.7 & 0 & 12.8 \\
\hline
\end{tabular}




\begin{tabular}{|c|c|c|c|c|c|c|c|c|c|}
\hline income & & & & & & & & & \\
\hline $\begin{array}{l}\text { Level of } \\
\text { income per } \\
\text { capita in the } \\
\text { world }\end{array}$ & 119 & 96 & 100 & 9 & 6 & 46 & 114 & 23 & 140 \\
\hline $\begin{array}{l}\text { Percent GDP } \\
\text { growth }\end{array}$ & 3.8 & 3.6 & 0.4 & -2.2 & 0 & 0.5 & 1.8 & 0 & 2 \\
\hline $\begin{array}{l}\text { Percentage } \\
\text { of exports of } \\
\text { GDP }\end{array}$ & 2 & 21 & 0 & 50 & 72 & 41 & 21 & 38 & 33 \\
\hline $\begin{array}{l}\text { Political } \\
\text { Structure }\end{array}$ & Republic & $\begin{array}{l}\text { Islam } \\
\text { ic } \\
\text { repub } \\
\text { lic }\end{array}$ & $\begin{array}{l}\text { Family } \\
\text { dynasty }\end{array}$ & $\begin{array}{l}\text { monarch } \\
\text { y }\end{array}$ & $\begin{array}{l}\text { Kingdo } \\
\mathrm{m}\end{array}$ & $\begin{array}{l}\text { Kingdo } \\
\mathrm{m}\end{array}$ & $\begin{array}{l}\text { Republi } \\
\mathrm{c}\end{array}$ & $\begin{array}{l}\text { Feder } \\
\text { ation }\end{array}$ & Republic \\
\hline $\begin{array}{l}\text { Governance } \\
\text { structure }\end{array}$ & State & State & $\begin{array}{l}\text { King of } \\
\text { the } \\
\text { executi } \\
\text { ve }\end{array}$ & $\begin{array}{l}\text { King of } \\
\text { the } \\
\text { executive }\end{array}$ & $\begin{array}{l}\text { King of } \\
\text { the } \\
\text { executi } \\
\text { ve }\end{array}$ & $\begin{array}{l}\text { King of } \\
\text { the } \\
\text { executi } \\
\text { ve }\end{array}$ & state & $\begin{array}{l}\text { Emira } \\
\text { tes }\end{array}$ & $\begin{array}{l}\text { Executiv } \\
\text { e election }\end{array}$ \\
\hline $\begin{array}{l}\text { Percentage } \\
\text { of women in } \\
\text { parliament }\end{array}$ & 2.4 & 4.1 & 3.3 & 0 & 0 & 0 & 12 & 0 & 0.7 \\
\hline $\begin{array}{l}\text { Percentage } \\
\text { of illiterate } \\
\text { population } \\
\text { over } 15 \\
\text { years }\end{array}$ & 45 & 24 & 10 & 18 & 19 & 24 & 25 & 24 & 53 \\
\hline $\begin{array}{l}\text { Of \% public } \\
\text { expenditure } \\
\text { for } \\
\text { education }\end{array}$ & 0 & 4.5 & 6 & 0 & 3.6 & 9.5 & 3.6 & 2 & 0 \\
\hline $\begin{array}{l}\text { \%Of public } \\
\text { expenditure } \\
\text { for health }\end{array}$ & 1.8 & 1.8 & 5 & 3.4 & 3.4 & 4.5 & 1.5 & 3.2 & 2.1 \\
\hline $\begin{array}{l}\text { Percentage } \\
\text { of illiterate } \\
\text { women over } \\
15 \text { years }\end{array}$ & 56 & 31 & 16 & 20 & 17 & 33 & 40 & 21 & 75 \\
\hline $\begin{array}{l}\text { Percentage } \\
\text { of male } \\
\text { unemploy- } \\
\text { ment in the } \\
\text { country }\end{array}$ & 5.1 & 11 & 12.6 & 0.8 & 1.8 & - & 8.6 & 1.7 & 10.1 \\
\hline
\end{tabular}

Source: For 2012: World Bank, World Development Report 2012: 196-197; for 2013: World Development Indicators (World Bank) 
Table 3 The progress of structural reforms in the Middle East countries

\begin{tabular}{|c|c|c|c|c|c|c|}
\hline \multirow{2}{*}{ Country } & \multicolumn{2}{|c|}{$\begin{array}{c}\text { Business and regulatory } \\
\text { reform }\end{array}$} & \multicolumn{2}{c|}{ Trade reform } \\
\cline { 2 - 8 } & $\begin{array}{c}\text { Progress of } \\
\text { reforms }\end{array}$ & Statues que & $\begin{array}{c}\text { Progress of } \\
\text { reforms }\end{array}$ & Statues que & $\begin{array}{c}\text { Progress } \\
\text { of reforms }\end{array}$ & Statues que \\
\hline Egypt & 24 & 28 & 11 & 29 & 100 & 60 \\
\hline Iran & 14 & 36 & 37 & 63 & 76 & 4 \\
\hline Jordan & 61 & 44 & 43 & 57 & 86 & 20 \\
\hline Kuwait & 14 & 42 & 16 & 77 & 0 & 0 \\
\hline Oman & 56 & 37 & 58 & 60 & 0 & 0 \\
\hline Qatar & 57 & 31 & 0 & 0 & 0 & 0 \\
\hline Saudi & 35 & 26 & 47 & 52 & 88 & 76 \\
\hline Syria & 0 & 21 & 2 & 17 & 0 & 0 \\
\hline UAE & 3 & 36 & 4 & 32 & 0 & 0 \\
\hline Yemen & 79 & 24 & 24 & 42 & 0 & 0 \\
\hline
\end{tabular}

The number " 100 " indicates the progress of structural reforms in countries throughout the world

Source: World Development Indicators 2013, the World Bank

This situation has created social and economic conditions, which cannot be solved by individuals alone. Short- and long-term plans that involve socio-political and economic management of the country have been designed to solve these complex problems. In these countries, the social and economic bodies are not allowed to flourish and almost all aspects of society are controlled by political leaders and the ruling elite society. We have studied the geography of the Middle East, the state, and beyond the state, the family which serves as a major employer in all matters. Citizens as subordinates comprise a kind of Rentier State Corporation because their profit does not destroy the state revenue, yet the interests are improving because the government dominates the economic, political, and social spheres. However, the government should create opportunities to improve the social, political, or economic status of the community.

Meanwhile, selecting political elites and senior executives in Middle Eastern politics is also an important issue. Here, election is not based on personal and professional competencies, but on installation and appointment. In other words, people achieve their posts not because of merit, but due to related factors, such as current affairs and rulers as well as the legitimacy and authority of the social traditions of religious communities. Apart from personal and group interests, traditions drive ordinary people to cooperate with the government. For example, in a country like Saudi Arabia (outside the traditional Arabic), the Wahhabi family has ruled the country for decades. This dynasty has become imprinted on the history of the country, thus demonstrating the unbreakable tradition of the elites. The elites of these countries know that if they lose these traditions, their effectiveness and legitimacy will also diminish, thereby resulting in disaster. Therefore, states are protected by the application of the norms of legitimacy and authority of the more successful elite; however, traditionalist scholars in the Middle East have conflicting state rules. Often, they deal with a range of traditional ideas of political development as well as socio-cultural thought. 
Table 4 The progress of structural reforms in the Middle East countries

\begin{tabular}{|c|c|c|c|c|c|c|}
\hline \multirow[b]{2}{*}{ Country } & \multicolumn{2}{|c|}{ Overall governance } & \multicolumn{2}{|c|}{$\begin{array}{l}\text { Accountability of the public } \\
\text { sector }\end{array}$} & \multicolumn{2}{|c|}{$\begin{array}{l}\text { Quality management of the } \\
\text { country }\end{array}$} \\
\hline & $\begin{array}{l}\text { Progress } \\
\text { of } \\
\text { reforms }\end{array}$ & Statuesque & $\begin{array}{l}\text { Progress of } \\
\text { reforms }\end{array}$ & Statuesque & $\begin{array}{l}\text { Progress of } \\
\text { reforms }\end{array}$ & Statuesque \\
\hline Egypt & 24 & 28 & 22 & 27 & 52 & 31 \\
\hline Iran & 14 & 36 & 11 & 41 & 35 & 28 \\
\hline Iraq & 0 & 9 & 0 & 11 & 0 & 7 \\
\hline Jordan & 61 & 44 & 42 & 41 & 77 & 46 \\
\hline Kuwait & 14 & 42 & 9 & 40 & 38 & 46 \\
\hline Oman & 56 & 37 & 28 & 26 & 85 & 52 \\
\hline Qatar & 57 & 31 & 29 & 22 & 87 & 44 \\
\hline Saudi & 35 & 26 & 31 & 14 & 58 & 43 \\
\hline Syria & 0 & 21 & 40 & 8 & 0 & 27 \\
\hline UAE & 3 & 36 & 12 & 26 & 7 & 49 \\
\hline Yemen & 79 & 27 & 47 & 24 & 85 & 27 \\
\hline
\end{tabular}

The governance and management of the country's best 100, indicates its ranking in the world

Source: World Development Indicators 2012, the World Bank

The following factors contribute to the legitimacy of the ruling elite (Fyrhy, 2004):

1. Continuing the traditions of the past, such as ethnicity, as the basis for the authority

2. Arabic nationalism as a revival of the past glory Caliphs

3. Oil revenues

4. Islamic religion

5. Rentier State

6. Expanding government bureaucracy.. 
In the social model of Max Weber and actions by Hoselitz (1953) (as described in the Tradition and Traditionalism section), unplanned and unconscious habits and disorders are often done within the community, and these may trigger resistance. Several factors help develop strong opposition toward any renewal of the crisis due to the performance of the elites. These factors are listed below.

1. The crisis is a major obstacle to economic development.

2. The Rentier State retains the benefits of its members. In that case, the business benefits are denied and they lose their followers.

3. The convergence is the result of the Caliphate's views, which fear political development.

4. Cohorts and government loyalists, along with intellectuals and political elites, have little in common with those who uphold economic and social development and always have a line of thought and action. The latter are often more radical than their leaders, and the government often quells any effort to initiate changes. Thus, cohorts and government loyalists play an important role in preserving traditions.

5. The traditionalist in the Middle East has been restored because of the personal attributes of the state.

Features include the following:

1. Authoritarianism

2. Dictatorship

3. Preservation of the Khalifa

4. Unity (in Islam, the church and state are not independent of each other) (Stenographer, 1994)

Considering that their own affairs are the norms in the Middle Eastern countries, underdevelopment will be difficult to resolve. However, development could still be achieved if the people and the rulers reach an agreement. Therefore, an internally consistent model for the development of the Middle East has been created. This model consists of several parts as identified below.

\section{Legitimacy}
a. Ruling rather than governing
b. Organized ruling
c. Aligning the interests of the ruling mass
d. Governance as a process based on trial and error

2. Philosophy of life
a. Positive individualism
b. Institutionalization of utility and efficiency
c. Futurism
d. In accordance with science and computing 
3. Educational system

a. Deductive thinking

b. According to the order

c. Systematic view

d. Economic culture

e. Social learning

f. Dynamic and coherent legal system

4. Methods and applications

a. An international perspective

b. Depoliticizing the decision process

c. Social institutionalism

d. Political partisanship

e. Diversifying the sources of national income

f. Economic development (Ibid)

\section{Conclusion}

In Middle Eastern countries, groups and institutions that are willing to change and improve development in their country. The rulers of these countries assume that development without government planning is in contrast with their legitimacy and authority, therefore they resist against any change. Because the ruling in the Middle Eastern countries that are in performance crisis.

They are extremely conservative and spend all its energy into maintaining their existing traditions. They are concerned that when the development of non-governmental organizations destroys tradition and thus it leads to loss of their legitimacy.

On the other hand, the Conservatives have the support of the community and groups who have common interests with the rulers. And these two influential groups in the Middle East; the conservative rulers and their fans, prevent the development of their countries in the socio - political and economic environment.The leaders and their supporters hold a particular identity and get stronger day by day due to the legitimacy and authority of the Islamic- Arabic tradition.

And the additional power of the rulers of these countries also delays development, because the traditions are opposed to political and social changes and development. 


\section{References}

Abedi-Ardekani, M .(2001). Tradition and Modernization. Qom: Cultural foundation of rayhaneh rasul, pp. 64.

Abedi-Ardekani, M. (2001). Tradition and Modernization.Qom: Cultural foundation of rayhaneh rasul, pp. 36.

Almond, G.A., \& verba, S. (1963). The civic culture, political attitudes, and democracy in five countries. Princeton, n.j: Princeton University Press.

Bashirieh, H. (2006). Political Sociology. Tehran: Ney, pp. 99.

Bashirieh, H. (2006). Political Sociology. Tehran: Ney. pp. 179.

Bashirieh, H. (2007). The history of political thought in the twentieth century (liberalism and conservatism). Tehran: Ney, Seventh edition.

Bashirieh, H. (2006). Political Sociology. Tehran: Ney, pp. 176.

Bashirieh, S.H. (1999). Traditionalism and Modernity. Journal Reviews, Issue I and II, pp. 4.

Chylkvt, R. (1996). Theories of development and underdevelopment (A. Saedi, Trans.). Tehran: The Institute of Modern Sciences.

Fyrhy, D. (2004). Power, knowledge, legitimacy. Tehran: Ney.

Hosseini, S. S. (2009). Economic Development and Prospects by the World Bank, Tehran: Tehran University (Ranked by the World Bank in the years before 2010).

Kouchaksaraei,M, J\& Bustami, M, R (2012). Structural Review of Rent Government and Its Effect on Democracy Process, Canadian Social Science, Vol 8, No 6,33-38.

Lypyst, M. (2004). Encyclopedia of Democracy (K. Fani, Trans.). Tehran: Iran's Foreign Ministry.

Maurice, B. (1386). Political modernity (Abdul Ahmadi, Trans.) Tehran: Second edition.

Nasr, S. (2001). Knowledge and the Sacred (F. Hadji Mirzaei, Trans.). Tehran: Blazing Research.

Norton, R. (2003). Challenging the legitimacy of the political order in the Middle East (M. Norouzi, Trans.). Tehran: Opinion-makers of Light Institute (Ranked by the World Bank in the years before 2010).

Oakeshott, M. (1962). Rationalism in politics and other, essay. London: melheven.

Panahi, M. (2012). Traditionalist Figures. Journal of Philosophy. 4 (63), 76.

Sai, A. (2004). Development of conflicting schools of Tehran. Tehran: Ghomes Publishing, pp. 36.

Savedji, M. H. (1999). A political magazine - economic. Numbers 149 and 150.

Seif Zadeh, S. H. (1994). Various theories about the ways modernization and political transformation. Tehran: Ghomes.

Shirazi, H. (2011). Politics and Government in the Middle East. Tehran: Samt. 
Stenographer, M . (1994). Intellect and development. Tehran: Scientific and Cultural Publications. pp. 107.

Stenographer, M. (1994). Intellect and development. Tehran: Scientific and Cultural Publications, pp. 124.

Tabatabaei, S. J. (2010). Arose from the Renaissance to the French Revolution. Tehran: The old and the new third issue. P. 81

Tabatabai, S. J. (2010). Arose from the Renaissance to the French Revolution. Tehran: The old and the new third issue, pp. 71.

Tabatabai, S. J. (2010). Arose from the Renaissance to the French Revolution. Tehran: The old and the new third issue, pp. 83.

"ICP 2011: International Comparison Program". Siteresources.worldbank.org. 2014-04-30. Retrieved 2014-05-20.

\section{Copyrights}

Copyright for this article is retained by the author(s), with first publication rights granted to the journal.

This is an open-access article distributed under the terms and conditions of the Creative Commons Attribution license (http://creativecommons.org/licenses/by/4.0/). 